\title{
Potret Pelaporan SPT Tahunan melalui E-Filing pada Masa Pandemi Covid-19
}

\section{Portrait of Annual SPT Reporting through E-Filing during the Covid-19 Pandemic}

\author{
Khy'sh Nusri Leapatra Chamalinda1, Fariyana Kusumawati ${ }^{2}$ \\ 1,2Universitas Trunojoyo Madura, Indonesia
}

A R T I C L E I N F O

Article History:

Received

Revised

Publish

Keywords:

E-filing, SPT, Tax Payer,

Covid-19 Pandemic

DOI:

10. $x x x x$

\begin{abstract}
A B S T R A C T
This study aims to describe and explore the annual SPT reporting service for individual taxpayers through e-filing at KPP Pratama Bangkalan with tax volunteers during the Covid-19 pandemic, as well as public responses in this case individual taxpayers regarding SPT reporting services. Annual individual taxpayers through e-filing at KPP Pratama Bangkalan during the Covid-19 pandemic. The method in this research is qualitative with a case study approach. The results of the study indicate that the preparation and implementation of the annual tax return reporting service through e-filing during the covid-19 pandemic has gone very well. Annual SPT reporting services during the pandemic are carried out through virtual Integrated Service Places (TPT). Various preparations for the implementation of SPT reporting services have been carried out, both by KPP Pratama Bangkalan and tax volunteers. In the process of SPT reporting services, they still face various obstacles. Various efforts have been made, so that this virtual TPT service can run optimally. In addition, the response of taxpayers to KPP services is that it has been going well. Taxpayers who report their Annual SPT are served as much as possible even though they are virtual.
\end{abstract}

\begin{abstract}
A B S T R A K
Penelitian ini bertujuan untuk bertujuan untuk menggambarkan serta mengeksplorasi tentang pelayanan pelaporan SPT Tahunan wajib pajak orang pribadi melalui e-filing pada KPP Pratama Bangkalan bersama relawan pajak di masa pandemi Covid-19, serta tanggapan masyarakat dalam hal ini wajib pajak orang pribadi mengenai pelayanan pelaporan SPT Tahunan wajib pajak orang pribadi melalui e-filing pada KPP Pratama Bangkalan di masa pandemi Covid-19. Metode dalam penelitian ini adalah kualitatif dengan pendekatan studi kasus. Hasil penelitian menunjukkan bahwa persiapan hingga pelaksanaan pelayanan pelaporan SPT Tahunan wajib pajak melalui e-filing di masa pandemi covid-19 sudah berjalan sangat baik. Pelayanan pelaporan SPT Tahunan pada masa pandemi dilaksanakan melalui Tempat Pelayanan Terpadu (TPT) virtual. Berbagai persiapan untuk pelaksanaan pelayanan pelaporan SPT telah dilakukan, baik oleh KPP Pratama Bangkalan maupun relawan pajak. Dalam proses pelayanan pelaporan SPT, masih menghadapi berbagai hambatan. Berbagai upaya telah dilakukan, agar pelayanan TPT virtual ini dapat berjalan maksimal. Selain itu, tanggapan wajib pajak terhadap pelayanan KPP yaitu sudah berjalan baik. Wajib pajak yang melaporkan SPT Tahunan dilayani semaksimal mungkin walaupun secara virual.
\end{abstract}

\section{PENDAHULUAN}

Penerimaan pajak menyumbang sekitar 84\% dari struktur Anggaran Pendapatan dan Belanja Negara (APBN). Salah satu sumber penerimaan atau pemasukan keuangan negara Indonesia ialah pajak. Pajak menurut Undang-Undang Nomor 28 Tahun 2007 didefinisikan sebagai "kontribusi wajib kepada negara yang terutang oleh orang pribadi atau badan yang bersifat memaksa berdasarkan Undang-Undang, dengan tidak mendapatkan imba- lan secara langsung, serta digunakan untuk keperluan negara bagi sebesar-besarnya kemakmuran rakyat". Laporan kinerja Direktorat Jenderal Pajak (DJP, 2020)

*Corresponding author: nusri.leapatra@trunojoyo.ac.id 
menunjukkan bahwa pencapaian penerimaan pajak tahun 2020 sebesar Rp 1.069,97 triliun atau 89,25\% dari target APBN tahun 2020 yaitu sebesar 1.198,82 triliun. Capaian tersebut lebih tinggi dari pencapaian penerimaan pajak tahun sebelumnya tahun 2019 yaitu 84,44\%. Pencapaian penerimaan pajak tentunya tidak lepas dari dukungan, komitmen, dan kerjasama antara otoritas pajak dengan wajib pajak (Darmayasa et al., 2020).

Pada tahun 2020, Indonesia dihadapkan masalah global yang serius yaitu adanya pandemi Corona Virus Disease 2019 (Covid-19). Pandemi ini dampaknya hampir dirasakan oleh seluruh sektor. Tidak hanya sektor kesehatan, sektor ekonomi pun turut terdampak adanya pandemi tersebut. Pemberlakuan pembatasan kegiatan masyarakat merupakan salah satu strategi pemerintah untuk mengendalikan peningkatan virus Covid-19 (Covid19.go.id, 2021). Diberlakukannya pembatasan aktivitas tersebut, dapat berimbas pada aktivitas bisnis dan perekonomian. Selain itu, pada tahun 2020 juga merupakan masa yang berat bagi seluruh dunia dan memberikan tantangan yang luar biasa, tak terkecuali bagi DJP sebagai institusi penghimpun penerimaan negara. Salah satu upaya pemerintah adalah memberikan sejumlah insentif pajak, yang diharapkan dapat mendukung penguatan transformasi ekonomi dan pemulihan ekonomi nasional (Kemenkeu.go.id, 2020). Menteri Keuangan, Sri Mulyani menyatakan bahwa DJP di tahun 2020 dihadapkan pada kondisi dimana harus lebih maksimal mengumpulkan penerimaan pajak, namun di sisi lain juga mendukungan dan membantu wajib pajak dalam mendapatkan insentif pajak (Kemenkeu.go.id, 2020).

Meningkatnya kepatuhan wajib pajak merupakan salah satu faktor untuk mendukung penerimaan pajak. Kepatuhan wajib pajak diharapkan dapat terus meningkat. Syakura \& Baridwan (2014) dalam penelitiannya menyatakan bahwa realisasi penerimaan pajak dipengaruhi oleh kepatuhan pajaks. Meskipun rendahnya kepatuhan pajak masih menjadi masalah yang kerap terjadi, namun DJP telah melakukan berbagai upaya, salah satunya yaitu meningkatkan kualitas pelayanan. Sejalan dengan penelitian Susmita \& Supadmi (2016) menyatakan bahwa kualitas pelayanan berpengaruh positif dan signifikan terhadap kepatuhan wajib pajak orang pribadi. Untuk mendukung tercapainya target pajak salah satunya dengan memberikan pelayanan prima kepada wajib pajak. Dimana DJP salah satunya telah mengembangkan aplikasi yang mempermudah wajib pajak dalam proses pendaftaran nomor pokok wajib pajak (NPWP) sampai dengan pelaporan Surat Pemberitahuan (SPT) Tahunan dalam bentuk aplikasi DJP online (Dwianika et al., 2018). Selain itu, wujud implementasi moderenisasi sistem perpajakan yang dilakukan oleh DJP, salah satunya yaiu menyediakan layanan e-filling. SPT tahunan untuk wajib pajak orang pribadi (WPOP) batas pelaporannya paling lambat tiga bulan setelah akhir tahun pajak. Dengan tersedianya layanan e-filing, diharapkan mempermudah dalam melaporkan SPT Tahunan wajib pajak orang pribadi $(1770,1770 S, 1770 S S)$ maupun badan (1771) secara online dan real time. Harapannya wajib pajak dapat menyampaikan SPT Tahunan secara online tanpa harus datang ke Kantor Pelayanan Pajak (KPP). Berkaitan dengan layanan e-filing, penelitian Agustiningsih \& Isroah (2016) menyatakan bahwa penerapan $e$-filing berpengaruh positif dan signifikan terhadap kepatuhan wajib pajak.

Pandemi Covid-19 juga berdampak pada layanan tatap muka kepada wajib pajak. Pembatasan layanan tatap muka di lingkungan unit kerja DJP dilakukan untuk mengantisipasi penyebaran Covid-19 dimulai pada 16 Maret 2020 sampai 14 Juni 2020, dan dievaluasi sesuai dengan perkembangan keadaan. Pelayanan tatap muka dihentikan sementara pada Tempat Pelayanan Terpadu (TPT) di KPP/KP2KP, Layanan di Luar Kantor (LDK), dan Pelayanan Terpadu Satu Pintu (PTSP) diseluruh wilayah Indonesia (DJP, 2020). Termasuk pelaporan SPT tahunan maupun masa tidak diterima secara langsung melalui KPP/KP2KP, melainkan pelaporan SPT tahunan dapat melalui e-filing/e-form dan untuk SPT masa dapat melaui pos tercatat. Hal tersebut merupakan upaya DJP dalam meminimalisir penularan Covid-19. Penghentian layanan tatap muka di unit kerja DJP tahun 2021 masih berlangsung. Akan tetapi, terdapat wajib pajak yang masih bergantung pada konsultasi tatap muka dengan pegawai pajak dalam melaporkan SPT tahunan PPh (DJP, 2020). Hal tersebut disebabkan karena masih terdapat wajib pajak belum mengerti atau belum memahami bagaimana menggunakan $e$-filling sebagai sarana melaporkan SPT.

Sejalan dengan hal tersebut, DJP melakukan inisiasi pembentukan Tax Center dengan menjalin kerjasama dengan Perguruan Tinggi. Salah satu program yang diluncurkan adalah relawan pajak. Diharapkan program ini dapat mendorong serta meningkatkan kesadaran wajib pajak dalam melaporkan SPT-nya (Yasa et al., 2021). Relawan pajak (tax volunteer) berperan dalam mengabdi kepada masyarakat melalui kegiatan pendampingan pelaporan SPT (Dwianika \& Sofia, 2019). Organisasi mitra di seluruh Indonesia yang menaungi program ini ialah Tax Center (Yasa et al., 2021). Salah satu Tax Center yang 
menjadi mitra DJP yaitu Tax Center pada Fakultas Ekonomi dan Bisnis Universitas Trunojoyo Madura (FEB UTM). Tax Center FEB UTM juga telah melaksanakan program relawan pajak sejak tahun 2019. Rekrutmen relawan pajak pun melalui berbagai tahapan yaitu dimula dari pengumuman rekrutmen, tes online seputar pajak, tes wawancara, sampai dengan pelatihan bagi calon relawan pajak.

Penelitian yang dilakukan oleh Yasa et al., (2021) bertujuan mengungkap persepsi wajib pajak terhadap kepuasan pendampingan yang dilakukan relawan pajak. Teknik penentuan sampel yang digunakan adalah purposive sampling dengan teknik wawancara dalam pengumpulan data. Hasil penelitian tersebut menunjukan bahwa kegiatan pendampingan oleh relawan pajak terhadap waib pajak dalam membantu pengisian SPT tahunan orang pribadi sangat efektif. Hal ini dapat dilihat dari kepuasan wajib pajak setelah mendapatkan pendampingan oleh relawan pajak. Selain itu, penelitian yang dilakukan Agustiningsih \& Isroah (2016) menyatakan bahwa tingkat pemahaman perpajakan, penerapan e-filing dan kesadaran wajib pajak berpengaruh positif dan signifikan terhadap kepatuhan wajib pajak. Perbedaan penelitian terdahulu tersebut dengan penelitian ini yaitu penulis menggunakan metode penelitian studi kasus, serta bertujuan untuk mengetahui bagaimana pelaporan SPT Tahunan pada masa pandemi covid19.

Selain itu, program relawan pajak FEB UTM mulai diadakan tahun 2019 dan ditugaskan untuk asistesi SPT Tahunan WP OP khusus 1770S dan 1770SS secara tatap muka di KPP Pratama Bangkalan. Namun di tahun 2021, ada perbedaan metode pendampingan/asistensi pelaporan SPT Tahunan terhadap wajib pajak yang disebabkan adanya pandemi Covid-19. Pada KPP Pratama Bangkalan, pembatasan layanan tatap muka pun dilakukan, dan pelayanan pelaporan SPT Tahunan dilakukan pada loket Tempat Pelayanan Terpadu (TPT) virtual. Sistem TPT virtual ini baru dilaksanakan KPP Pratama Bangkalan pada tahun 2021. Selain itu, penerimaan SPT Tahunan PPh wajib pajak orang pribadi untuk tahun pajak 20172020 pada KPP Pratama Bangkalan terus mengalami peningkatan. Dimana pada tahun 2017 penerimaan SPT sebanyak 30.459, tahun 2018 mencapai 32.114, tahun 2019 sebanyak 33.223, dan di tahun 2020 meskipun ditengah pandemi covid 19 penerimaan SPT Tahunan mencapai 46.429. Hal ini menjadi alasan peneliti melakukan penelitian pada KPP Pratama Bangkalan, dan menjadi keterbaruan penelitian ini karena belum banyak di eksplorasi pada penelitian sebelumnya berkaitan dengan TPT virtual.

Berdasarkan fenomena tersebut, penelitian ini bertujuan untuk menggambarkan serta mengekplorasi pelayanan dalam pelaporan SPT Tahunan wajib pajak orang pribadi melalui e-filing pada KPP Pratama Bangkalan bersama relawan pajak di masa pandemi Covid-19, serta menggambarkan tanggapan wajib pajak mengenai pelayanan pelaporan SPT Tahunan WP OP melalui $e$-filing di masa pandemi covid-19 pada KPP Pratama Bangkalan. Kontribusi penelitian ini antara lain diharapkan dapat menjadi bahan evaluasi bagi KPP dan unit kerja di lingkungan DJP dalam memberikan pelayanan bagi wajib pajak khususnya secara virtual pada masa pandemi covid-19. Selain itu, diharapkan bagi relawan pajak untuk dapat meningkatkan dan memaksimalkan dalam melakukan asistensi pengisian SPT Tahunan bersama KPP, dan bagi wajib pajak untuk tetap patuh melaporkan SPT Tahunan meskipun di masa pandemi covid-19, sehingga diharapkan dapat meningkatkan kepatuhan pajak.

\section{TELAAH LITERATUR}

Teori atribusi (atribution theory) digunakan untuk menggambarkan serta mengekplorasi pelayanan pelaporan SPT Tahunan wajib pajak orang pribadi melalui e-filing pada KPP Pratama Bangkalan bersama relawan pajak di masa pandemi Covid-19, serta menggambarkan tanggapan masyarakat dalam hal ini wajib pajak orang pribadi mengenai pelayanan tersebut. Teori atribusi dikembangkan oleh Fritz Heider tahun 1958 yang mengargumentasikan bahwa perilaku atau tindakan seseorang ditentukan oleh kombinasi antara kekuatan internal yaitu faktor-faktor yang berasal dari diri seseorang (misalnya kepribadian, persepsi diri, kemampuan, dan motivasi), dan juga kekuatan eksternal yaitu faktor-faktor yang berasal dari luar diri seseorang (misalnya kondisi sosial, nilai-nilai sosial, dan pandangan masyarakat) (Suartana, 2010). Selain itu, teori atribusi menjelaskan bagaimana individu dapat menjelaskan penyebab dari perilaku yang ada disekitar mereka (Weiner, 2010). Teori atribusi dengan penelitian ini relevansinya berkaitan dengan penentuan sikap wajib pajak untuk patuh atau tidak patuh dalam menyelesaikan kewajiban perpajakannya yang dipengaruhi oleh atribusi internal maupun eksternal. Intensi wajib pajak untuk menggunakan $e$-filling dalam pelaporan SPT, erat kaitannya dengan perilaku wajib pajak yang disebabkan oleh dorongan 
eksternal. Kepatuhan wajib pajak disebabkan pula oleh atribusi eksternal melalui peran relawan pajak yang dipercayai mampu memberi kontribusi positif.

Kepatuhan pajak menjadi hal yang penting untuk ditingkatkan. Terjadinya ketidakpatuhan pajak secara bersamaan dapat menimbulkan upaya penghindaran pajak yang berdampak pada berkurangnya penerimaan serta penyetoran dana pajak ke kas negara (Putri \& Setiawan, 2017). Kepatuhan pajak (tax compliance) dapat didefinisikan sebagai kesadaran wajib pajak untuk patuh terhadap perpajakan perpajakan di suatu negara. Sistem pemungutan pajak di Indonesia saat ini menganut selfassessment system. Dimana kepatuhan pajak menjadi salah satu faktor terpenting untuk meningkatnya penerimaan pajak dan pelaksanaan kewajiban perpajakan. Pasalnya, self assessment system menunjukkan bahwa pemerintah memberikan kepercayaan kepada wajib pajak untuk menghitung, menyetor, dan melaporkan sendiri kewajiban perpajakannya. Kepatuhan pajak tentunya dipengaruhi oleh berbagai faktor.

Berdasarkan penelitian Susmita \& Supadmi (2016) menyatakan bahwa kualitas pelayanan, sanksi perpajakan, dan penerapan e-filing berpengaruh positif dan signifikan terhadap kepatuhan WP OP. Sejalan dengan penelitian Putri \& Setiawan (2017) yang menyatakan bahwa kesadaran wajib pajak, pengetahuan dan pemahaman peraturan perpajakan, kualitas pelayanan dan sanksi perpajakan berpengaruh positif terhadap kepatuhan wajib pajak. Umumnya, kepatuhan pajak dibagi menjadi dua yaitu 1) Pertama, kepatuhan secara administratif atau secara formal (sejauh mana wajib pajak patuh terhadap persyaratan prosedural dan administrasi pajak, termasuk mengenai syarat pelaporan serta waktu untuk menyampaikan dan membayar pajak), dan 2) Kedua, kepatuhan secara teknis atau materiel, yang mengacu pada perhitungan jumlah beban pajak secara benar (DDTC.go.id, 2020). Kepatuhan dapat diidentifikasi berdasarkan pada kepatuhan wajib pajak dalam mendaftarkan diri, kepatuhan wajib pajak untuk melaporkan SPT secara benar, lengkap dan jelas, serta kepatuhan dalam pembayaran piutang perpajakan (DDTC.go.id, 2020).

Penelitian yang dilakukan oleh Yasa et al., (2021) bertujuan untuk menggali persepsi wajib pajak atas kepuasan pendampingan yang dilakukan oleh relawan pajak di lokasi penempatan relawan pajak. Teknik penentuan sampel yang digunakan dalam penelitian ini adalah purposive sampling dengan teknik wawancara dalam pengumpulan data penelitian. Hasil penelitian menunjukan bahwa kegiatan pendampingan wajib pajak oleh relawan pajak dalam membantu pengisian SPT tahunan orang pribadi sangat efektif. Hal ini dapat dilihat dari kepuasan wajib pajak setelah mendapatkan pendampingan oleh relawan pajak. Selain itu, penelitian yang dilakukan oleh Agustiningsih \& Isroah (2016) bahwa penerapan e-filing, tingkat pemahaman perpajakan dan kesadaran wajib pajak berpengaruh positif dan signifikan terhadap kepatuhan wajib pajak. Perbedaan penelitian ini dengan penelitian terdahulu tersebut adalah penelitian ini menggunakan metode penelitian studi kasus, dan bertujuan untuk mengetahui bagaimana pelaporan SPT Tahunan pada masa pandemi covid-19.

Pesatnya perkembangan teknologi, sejalan dengan kebutuhan wajib pajak yang terus berkembang. Berkaitan dengan kebutuhan wajib pajak, dalam hal ini DJP perlu untuk senantiasa memperhatikan kepuasan wajib pajak agar peningkatan kepatuhan tercapai (Artawan et al., 2020). Tentunya hal ini menjadi tantangan tersendiri bagi DJP. Melakukan beberapa terobosan baru serta penyesuaian terhadap kebijakan perpajakan dan layanan dengan memanfaatkan perkembangan teknologi, merupakan hal yang perlu DJP lakukan. Salah satu wujudnya dapa dijumpai pada layanan-layanan elektronik berbasis teknologi informasi, diantaranya adalah: e-faktur, e-registration, e-SPT, e-billing, e-filling, dan lain sebagainya. E-filing merupakan suatu cara untuk menyampaikan Surat Pemberitahuan (SPT) secara elektronik yang dilakukan secara online dan real time melalui internet pada website DJP (http://www.pajak.go.id) atau Penyedia Jasa Aplikasi Perpajakan (PJAP). Untuk penyampaikan laporan SPT Tahunan PPh orang pribadi $(1770,1770$, 1770SS) maupun SPT tahunan PPh badan (1771), wajib pajak dapat mengisi dan menyampaikan laporan SPTnya pada aplikasi e-filing di DJP online. Disediakan formulir pengisian langsung pada aplikasi e-filing untuk jenis SPT 1770SS dan 1770S. Selain itu, penyampaian laporan SPT pajak lainnya terutama jenis SPT 1770 maupun 1771, e-filing di DJP online menyediakan fasilitas penyampaian SPT berupa ungggah SPT yang telah dibuat melalui aplikasi e-SPT maupun e-FORM. SPT yang telah dibuat melalui aplikasi tersebut dapat disampaikan secara online tanpa harus datang ke KPP.

Beberapa tahun terakhir, DJP telah mendorong pembentukan relawan pajak. Hal tersebut tidak lain bertujuan untuk meningkatkan kepatuhan wajib pajak, serta salah satunya untuk mendorong kegiatan penyuluhan perpajakan. Kegiatan relawan ini dilaksanakan sebagai bentuk edukasi perpajakan yang melibatkan pihak ketiga (DJP, 2021). Program ini menyasar para mahasiswa baik yang mempunyai latar 
belakang ilmu perpajakan maupun non-perpajakan. Konsep program relawan pajak ini melibatkan tax center atau Program Studi Perpajakan yang ada di berbagai kampus, baik perguruan swasta atau perguruan negeri. Penerapannya adalah melibatkan mahasiswa yang berperan sebagai relawan pajak di berbagai KPP di Indonesia, khususnya KPP di sekitar kampus. Peran serta relawan pajak secara mendasar adalah membantu asistensi pelaporan SPT Tahunan dan tidak menutup kemungkinan terlibat dalam beberapa kegiatan peyuluhan yang diselenggarakan oleh KPP. Program relawan pajak mulai dilaksanakan sejak tahun 2017, dengan melakukan piloting standardisasi proses bisnis yang meliputi pendaftaran, pelatihan, penyeleksian, dan pendayagunaan relawan pajak (Edukasi pajak.go.id, 2020).

Setiap tax center di suatu Perguruan Tinggi pada umumnya mempunyai peranan dalam mengembangkan berbagai kegiatan dengan karakteristik masing-masing, termasuk dalam melaksanakan kegiatan program relawan pajak. Kegiatan relawan pajak pada Tax Center FEB UTM dikoordinasikan oleh pengurus tax center yang juga merupakan Dosen di lingkungan FEB UTM. Selain itu, relawan pajak nantinya akan tersegmentasi menjadi empat petugas (Edukasi pajak.go.id, 2020) yaitu pertama sebagai petugas pengawas, dimana relawan pajak bertugas melakukan pengawasan pengelolaan dan membantu relawan pajak lainnya. Kedua, sebagai petugas asistensi yaitu relawan pajak bertugas melakukan kegiatan asistensi. Ketiga, sebagai petugas registrasi yaitu relawan bertugas melakukan kegiatan registrasi. Keempat, sebagai petugas pendukung yaitu relawan pajak bertugas melaksanakan fungsi pendukung, seperti dukungan peralatan, publishing, sosial media, pembuatan email, dan sebagainya.

\section{METODE PENELITIAN}

Menurut Creswell (2014) pendekatan studi kasus merupakan strategi penelitian dimana peneliti menyelidiki suatu program, peristiwa, aktivitas, proses, atau sekelompok individu secara cermat. Peneliti mengumpulkan informasi secara lengkap menggunakan prosedur pengumpulan data berdasarkan waktu yang telah ditentukan. Pemilihan metode kualitatif dengan pendekatan studi kasus bertujuan untuk mendapatkan "kedalaman" pemahaman tentang pelayanan pelaporan SPT Tahunan WP OP melalui $e$ filing pada KPP Pratama Bangkalan bersama relawan pajak di masa pandemi covid-19. Selain itu, paradigma penelitian yang digunakan adalah paradigma interpretif, dimana merupakan cara pandang yang bertujuan untuk memahami secara mendalam tentang mengapa realita itu terjadi (Kamayanti, 2016).

KPP Pratama Bangkalan dipilih karena di KPP Pratama Bangkalan TPT virtual baru dilaksanakan pada tahun 2021 serta penerimaan SPT Tahunan PPh wajib pajak orang pribadi untuk tahun pajak 20172020 pada KPP Pratama Bangkalan terus mengalami peningkatan. Informan penelitian ini adalah Pegawai KPP Pratama Bangkalan, Relawan pajak Tax Center FEB UTM tahun 2021 dan Wajib pajak orang pribadi (WPOP). Adapun kriteria informan dijabarkan sebagai berikut:

1) Pegawai KPP Pratama Bangkalan. Pegawai seksi pelayanan dipilih sebagai informan pada penelitian ini karena berhubungan langsung saat memberikan pelatihan bagi relawan pajak dan mendampingi saat asistensi pelayanan berlangsung.

2) Relawan pajak Tax Center FEB UTM tahun 2021. Hal tersebut dilakukan untuk memperoleh informasi yang lebih mendalam tentang bagaimana pelayanan pajak yang dilakukan saat pandemi covid-19. Wawancara dilakukan dengan menyebarkan kuesioner pertanyaan kepada relawan pajak.

3) Wajib pajak orang pribadi (WPOP), wajib pajak orang pribadi yang terdaftar di KPP Pratama Bangkalan yang berprofesi sebagai karyawan/pegawai, yang telah melaporkan SPT Tahunan 2020 di tahun 2021 menggunakan e-filing dan memanfaatkan layanan pajak secara virtual/datang langsung ke KPP sehingga menjadi informasi tambahan bagi penulis.

Penggunakan data primer pada penelitian berupa data yang diperoleh dari hasil wawancara secara langsung dengan informan sebagai objek dalam peneltian ini yaitu pegawai KPP Pratama Bangkalan, relawan pajak FEB UTM tahun 2021, dan wajib pajak orang pribadi. Selain itu, juga terdapat sumber data sekunder yang mengacu pada hasil penelusuran kepustakaan yang berkaitan dengan pelaporan SPT Tahunan melalui $e$-filing. Adapun sumber data yang diperoleh dari hasil penelusuran kepustakaan adalah literatur, UU KUP, UU PPh, serta website pajak seperti www.pajak.go.id, www.ortax.org, instagram KPP Pratama Bangkalan dan sebagainya.

Umumnya dalam penelitian kualitatif, peneliti mengumpulkan berbagai jenis data dan memanfaatkan waktu untuk mengumpulkan informasi di lokasi penelitian (Creswell, 2014). Prosedur pengumpulan data penelitian ini (Creswell, 2014) yaitu: 1) Observasi, peneliti terjun langsung ke lapangan 
untuk melakukan pengamatan terhadap fenomena yang akan diteliti. Dalam pengamatan ini, peneliti merekam/mencatat perilaku maupun aktivitas individu di lokasi penelitian baik secara terstruktur maupun semiterstruktur; 2) Wawancara: peneliti mewawancarai informan secara tatap muka langsung dan juga secara virtual, serta menggunakan wawancara semi terstruktur; dan 3) Dokumentasi: Selama proses peneltian, peneliti dapat mengumpulkan dokumen-dokumen kualitatif. Dengan kata lain, dokumentasi merupakan pelengkap dari penggunaan metode observasi dan wawancara dalam penelitian kualitatif, yang bisa berbentuk tulisan, gambar atau karya-karya monumental seseorang.

Meriam (1998) dan Marshall \& Rossman (1988) dalam (Creswell, 2014) menyatakan bahwa dalam penelitian kualitatif yaitu pengumpulan dan analisis data harus berlangsung secara serempak atau bersamaan. Analisis data dapat diartikan sebagai proses yang terus berkelanjutan selama penelitian berlangsung (Creswell, 2014). Stake mengungkapkan terdapat 4 bentuk analisis data beserta interpretasinya dalam penelitian studi kasus yaitu: 1) Pengumpulan kategori; 2) Interpretasi langsung; 3) Peneliti membentuk pola dan mencari kesepadanan antar dua kategori atau lebih, serta 4) Peneliti mengembangkan generalisasi naturalistik melalui analisis data.

\section{HASIL PENELITIAN DAN PEMBAHASAN}

Pelaporan SPT tahunan untuk wajib pajak orang pribadi dilaksanakan paling lambat tiga bulan setelah akhir tahun pajak. Hal tersebut telah tertuang dalam UU Nomor 28 Tahun 2007 tentang KUP. Dengan adanya layanan e-filing, wajib pajak dapat menyampaikan/melaporkan SPT secara elektronik yang dilakukan secara online dan real time melalui internet pada website DJP (http://www.pajak.go.id) atau Penyedia Jasa Aplikasi Perpajakan (PJAP). SPT yang telah dibuat melalui aplikasi-aplikasi tersebut dapat disampaikan secara online tanpa harus datang ke KPP. Informasi dari Bapak Agus (pegawai KPP Pratama Bangkalan seksi pelayanan) dan juga instagram KPP Pratama Bangkalan (@pajakbangkalan), untuk pelaporan SPT Tahunan Tahun 2020 di tahun 2021, KPP Pratama Bangkalan menyediakan layanan asistensi pengisian SPT Tahunan secara virtual melalui zoom. Zoom dapat diakses oleh wajib pajak pada laman bit.ly/asistensivirtualspt serta id 6446442021 dan passcode 644 2021, sedangkan wajib pajak juga dapat mengakses tutorial pengisian SPT Tahunan pada laman bit.ly/spt2021. Hal ini ditujukan bagi wajib pajak yang ingin mendapatkan pelayanan secara virtual. Tidak hanya itu, bagi wajib pajak yang ingin datang langsung ke KPP, juga bisa dengan terlebih dahulu mengisi aplikasi kunjung pajak yaitu di alam kunjung.pajak.go.id. Penambahan menu layanan aplikasi kunjung pajak ini ditujukan untuk wajib pajak dalam pengambilan tiket antrean layanan, khusus konsultasi terkait SPT Tahunan. Jangka waktu booking antrean untuk seluruh layanan ini adalah 3 hari kerja.

Pelayanan pelaporan SPT Tahunan tahun 2021 oleh KPP Pratama Bangkalan melaksanakan pelayanan melalui TPT virtual. KPP bersama relawan pajak mengacu pada pedoman petugas asistensi virtual yang diberikan oleh Seksi Pelayanan KPP Pratama Bangkalan. Dalam pedoman tersebut, petugas asistensi virtual dibagi menjadi 4 (empat) yaitu: 1) Host Pengarah Pelayanan, 2) Petugas Loket Virtual, 3) Petugas Efin, dan 4) Petugas Pemeriksaan Efin. Dalam melaksanakan tugasnya, relawan pajak berada pada posisi kedua yaitu sebagai Petugas Loket Virtual. Sebelum asistensi SPT Tahunan di arahkan ke Petugas Loket Virtual, wajib pajak setelah join melalui zoom, terlebih dahulu akan diarahkan ke Host Pengarah Pelayanan. Selain itu, menurut Inge (salah satu relawan pajak), pada tahun 2021 terdapat 31 relawan pajak pada Tax Center FEB UTM. Perekrutan relawan pajak pada Tax Center FEB UTM dilakukan melalui proses yang bertahap. Mulai dari pengumuman perekrutan, tes online terkait wawasan perpajakan, tes wawancara, pelatihan calon relawan pajak, hingga pengukuhan bagi relawan pajak tahun 2021. Relawan pajak mulai bertugas asistensi bersama KPP Pratama Bangkalan secara virual pada bulan Maret hingga April 2021. Asistensi pelayanan pelaporan SPT Tahunan WP OP oleh relawan pajak khusus untuk melayani wajib pajak dengan kategori karyawan yang menggunakan jenis SPT Tahunan 1770S dan 1770SS.

Pelayanan pelaporan SPT Tahunan secara virtual oleh KPP Pratama Bangkalan bersama relawan pajak membutuhkan berbagai persiapan. Berikut penjelasan Bapak Agus:

"Tentunya persiapannya dimulai dari pembentukan tim Satgas SPT Tahunan. Untuk tahun 2021 ini kita libatkan seluruh pelaksana bahkan seluruh pegawai account representative (AR) juga sampai seluruh komponen di KPP Pratama Bangkalan kita libatkan. Hal tersebut mengacu pada kondisi jam kerja yang terbagi dalam Work From Home (WFH) dan Work From Office (WFO) yang nantinya diharapkan juga ikut melayani Wajib Pajak yang ingin menyampaikan SPT Tahunannya. Selain itu 
kita juga melakukan sosialisasi terlebih dahulu tentang e-filing kepada masyarakat. Kita juga mempersiapkan TPT (Tempat Pelayanan Terpadu) secara virtual. Persiapan selanjutnya yaitu koordinasi dengan Tax Centre FEB UTM yang tentunya untuk mengajak para relawan pajak untuk berkolaborasi atau bekerjasama sesuai dengan fungsinya dan nantinya dilibatkan pada tim penerimaan SPT Tahunan secara virtual. Sesungguhnya kita banyak membutuhkan tenaga untuk melakukan pelayanan pada penyampaian SPT Tahunan ini namun jika hanya mengandalkan pegawai KPP saja kemungkinan besar tidak optimal. Sebelumnya kita juga berinovasi dengan melakukan trial terlebih dahulu dengan melibatkan relawan pajak atau semacam pemberian pelatihan dan pembekalan berupa pedoman kepada relawan pajak agar siap dalam melayani wajip pajak nantinya. Yang terakhir tidak kalah pentingnya yaitu mempersiapkan sarana dan prasarana".

"Awalnya kita tetap mengharapkan wajib pajak dapat melaporkan kewajiban pajaknya secara mandiri dengan e-filing. Namun kita juga melihat kondisi masyarakat disini memang tingkat kesadaran serta pengetahuannya yang masih kurang, akhirnya kita running dengan TPT (Tempat Pelayanan Terpadu) virtual itu. Kita sebelumnya juga telah memberikan sosialisasi kepada masyarakat berupa spanduk, leaflet dan brosur serta mengirim surat juga kepada dinas-dinas di kabupaten Sampang dan Bangkalan terkait fasilitas TPT (Tempat Pelayanan Terpadu) virtual ini. Dengan berjalannya waktu tim yang sudah dibentuk serta dengan relawan pajak kita jadwalkan dan kita siagakan di Zoom Meeting dengan waktu sesi pertama yaitu dari jam 8 sampai jam 12 siang lalu dilanjutkan dari jam 12 sampai jam 4 sore dengan pembagian 15 orang untuk masing-masing sesi (belum termasuk relawan pajak), kemudian Wajib Pajak dipersilahkan masuk untuk melakan pelayanan perpajakannya".

Terlihat berbagai tindakan yang dilakukan oleh KPP untuk persiapan pelayanan pelaporan SPT Tahunan dengan e-filing melalui TPT virtual. Persiapan antara lain dimulai dengan pembentukan Tim Satgas dengan melibatkan seluruh pelaksana bahkan seluruh pegawai pajak di bagian Account Representative (AR), dan seluruh komponen KPP Pratama Bangkalan juga dilibatkan. Melakukan sosialisasi kepada masyarakat (berupa spanduk, leaflet dan brosur serta mengirim surat juga kepada dinas-dinas di kabupaten Sampang dan Bangkalan) terkait fasilitas TPT virtual. Persiapan koordinasi dilakukan bersama Tax Center FEB UTM beserta relawan pajak. Memberikan pelatihan dan pembekalan, salah satunya berupa pedoman TPT Virtual kepada relawan pajak. Juga mempersiapkan sarana dan prasarana (laptop, komputer, headseat, internet, zoom dan sebagainya). Selain itu, TPT virtual disiagakan melalui zoom yang dalam sehari terdapat 2 shift (pagi dan siang) dan sekitar 15 orang yang bertugas.

Relawan pajak FEB UTM di tahun 2021 terdapat 31 orang yang terdiri dari 26 mahasiswa Jurusan Akuntansi, 4 mahasiswa Jurusan Ekonomi Pembangunan, dan 1 mahasiswa Jurusan Manajemen. Tanggapan relawan pajak berkaitan dengan pelayanan pelaporan SPT tahunan wajib pajak melalui e-filing pada KPP Pratama Bangkalan di masa pandemi covid-19, dilakukan dengan cara menyebarkan kuesioner penelitian. Dalam kuesioner penelitian, disajikan beberapa pertanyaan berkaitan dengan persiapan, pelaksanaan, hambatan, upaya, dan saran berkaitan dengan asistensi pelayanan pelaporan SPT tahunan wajib pajak melalui $e$-filing oleh relawan pajak bersama KPP Pratama Bangkalan di masa pandemi covid19.

Persiapan juga dilakukan oleh Tax Center FEB UTM bersama KPP Pratama Bangkalan untuk membekali relawan pajak pada saat nantinya melakukan asistensi pelaporan SPT Tahunan. Pelayanan pelaporan SPT ini dilakukan secara virtual, mengingat di tahun 2021 pandemi covid-19 belum berakhir. Kuesioner penelitian disebar kepada 31 relawan, dan hanya 29 kuesioner yang kembali. Dari 29 relawan pajak, 79,3\% menyatakan bahwa persiapan pelayanan pelaporan SPT Tahunan melalui TPT virtual bersama KPP Pratama Bangkalan tahun 2021 berjalan sangat baik.

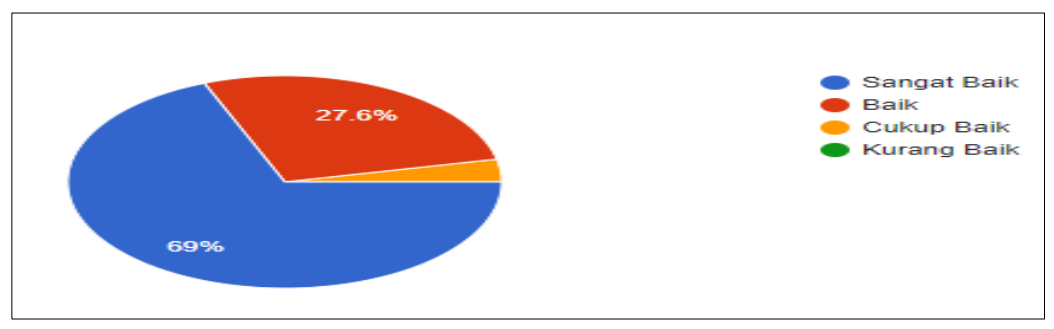




\section{Gambar 1. Respon Relawan Pajak terhadap Persiapan TPT Virtual}

Sumber: Data Diolah, 2021

Penjelasan Nike dan Ainun (relawan pajak) berkaitan dengan persiapan pelaporan SPT Tahunan bersama KPP Pratama Bangkalan, yang menjelaskan bahwa:

"Persiapan sebelum melakukan asistensi (jauh sebelum relawan pajak bertugas), KPP memberikan pelatihan secara virtual, KPP juga memberikan kesempatan bagi perwakilan Relawan Pajak untuk mendapat pengarahan secara langsung di KPP. Lalu sharing pengarahan yang didapat dengan teman-teman Relawan Pajak yang lain secara virtual. KPP memberikan kesempatan untuk melakukan training asistensi pada perwakilan Relawan Pajak. Melakukan praktik asistensi bersama pengelola Tax Center dan Relawan Pajak Persiapan sebelum bertugas saat melakukan asistensi. KPP memberikan breafing atau informasi yang harus dilakukan ketika telah memberikan asistensi pada WP" (Nike)

"Secara pribadi saya menyiapkan persiapan sebagai berikut untuk asistensi yaitu 1. Menyiapkan laptop, jaringan internet dan aplikasi zoom termasuk virtual background 2. Menyiapkan lampiran dokumen pendukung seperti contoh bukti potong 1721-A2 dan bukti potong final apabila pelapor kebingungan saat menunjukkan data 3. Menyiapkan website djponline.pajak.go.id 4. Menyiapkan kalimat pembuka untuk menyapa pelapor secara sopan 5. Menyiapkan beberapa pertanyaan untuk tujuan pelaporan" (Ainun)

Tidak hanya KPP, relawan pajak pun juga turut melakukan persiapan untuk pelayanan pelaporan SPT Tahunan secara virtual. Sejalan dengan penjelasan relawan pajak tersebut, persiapan yang dilakukan antara lain yaitu relawan pajak mengikuti pembekalan dan pelatihan terkait pelaporan SPT Tahunan baik dari KPP Pratama Bangkalan dan juga Tax Center, memahami pedoman TPT virtual, mempersiapkan sarana dan prasarana (laptop, komputer, headseat, internet, zoom dan sebagainya), serta melakukan sharing dengan relawan pajak lainnya. Selain tahap persiapan, dari segi pelaksanaan pun 44,8\% menyatakan bahwa pelaksanaan asistensi pelaporan SPT Tahunan secara virtual bersama KPP Pratama Bangkalan tahun 2021 berjalan sangat baik.

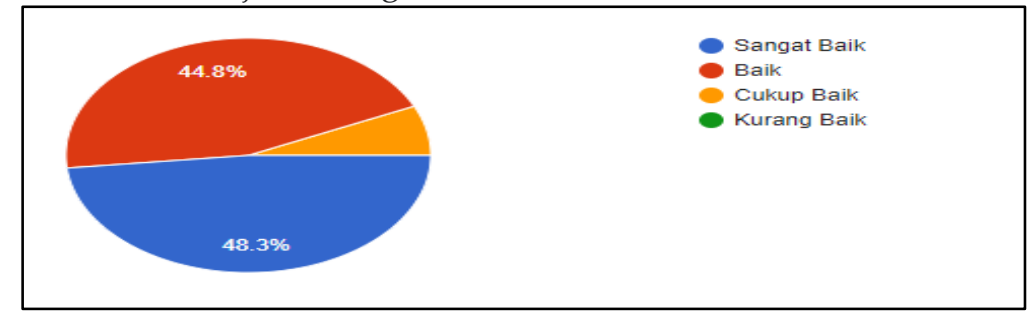

Gambar 2. Respon Relawan Pajak terhadap Pelaksanaan TPT Virtual Sumber: Data Diolah, 2021 bahwa:

Hal tersebut sejalan dengan penjelasan Ameliatus dan Farida (relawan pajak) yang menyatakan

"Pelaksanaan sangat baik dan profesional. Meskipun dalam masa pandemi dan harus dilakukan secara online, kami masih dapat membantu wajib pajak dalam melaporkan SPT tahunanan mereka. Selain memperoleh pengalaman, saya sebagai relawan pajak dapat memperoleh ilmu baru saat berhadapan langsung dengan orang lain" (Ameliatus)

"Menurut saya cukup baik karena disaat pandemi ini kita masih bisa menjadi produktif, meskipun kadang terhalang oleh sinyal dan jarak tempat yang jauh sehingga terkadang menjadi salah satu kendala miss komunikasi" (Farida)

Berbagai persiapan dan tindakan yang dilakukan oleh KPP Pratama Bangkalan dan juga relawan pajak tersebut, tentunya diharapkan dapat mendorong wajib pajak untuk patuh dalam melaporkan SPT Tahunan. Mulai dari persiapan pembentukan tim satgas dengan melibatkan seluruh pelaksana, melakukan sosialisasi kepada masyarakat terkait fasilitas TPT virtual, persiapan koordinasi dilakukan bersama Tax Center FEB UTM beserta relawan pajak, memberikan pelatihan dan pembekalan (salah satunya berupa pedoman TPT virtual) kepada relawan pajak, mempersiapkan sarana dan prasarana, serta menyusun 
jadwal penugasan tiap shift. Hal tersebut diharapkan dapat menjadi atribusi eksternal bagi wajib pajak untuk patuh dalam melaporkan SPT Tahunan meskipun dimasa pandemi covid-19.

Pelaksanaan pelayanan pelaporan SPT Tahunan wajib pajak orang pribadi secara virtual oleh KPP Pratama Bangkalan bersama relawan pajak dilaksanakan pada bulan Maret hingga April 2021. Dalam pelaksanaannya sudah berjalan sangat baik, namun dalam proses pelayanannya masih menghadapi berbagai hambatan dan berbagai upaya sudah dilakukan. Berikut penjelasan Bapak Agus:

"Penyusunan tim satgas kami terkendala dalam pembagian jadwal WFH dan WFO kapan harus melakukan tugasnya masing-masing dan bergabung dalam tim pelayanan. Dalam prakteknya ternyata masih banyak masyarakat yang masih belum paham mengenai e-filing virtual, meskipun telah dilakukan sosialisasi di jauh hari sebelumya tetapi masyakakat tetap datang ke kantor untuk melakukan pelayanan perpajakannya. Selain itu wajib pajak yang melakukan TPT virtual kadang kala terkendala sinyal jadi sempat beberapa kali yang agak kesusahan untuk berkomunikasi dengan baik putus-putus dan sebagainya ketika masuk dalam zoom meeting. Dan juga kadang terkendala sinyal atau jaringan internet. Kemudian terkait dengan kendala relawan sendiri yaitu terakit koneksi yang digunakan serta hambatan dalam pengisian e-filing dan juga jenis SPT yang bisa di handle oleh relawan pajak sendiri sementara hanya yang karyawan yaitu jenis SPT 1770 S dan 1170 SS saja."

\begin{abstract}
"Upaya yang dilakukan dalam penyusunan tim satgas yaitu kami harus pintar-pintar dalam mengatur pembagian jadwal agar tim satgas tetap menjalankan tugas fungsi utamanya disandingi dengan tugas menjadi tim pelayanan. Upaya lain yang kami lakukan yaitu akhirnya kita membuat inovasi baru lagi bagaimana cara mengatasi wajib pajak yang tetap datang ke kantor untuk melakukan pelayanan perpajakannya. Misal seperti protokol kesehatannya bagaimana atau teknisnya seperti apa jadi kita dalam setiap pelaksanannya selalu berunding untuk mengatasi hambatanhambatan yang kemungkinan akan terjadi. Pada akhirnya disepakati oleh kebijakan pimpinan kami bahwasannya KPP Pratama Bangkalan tetap menerima Wajib Pajak yang datang langsung ke kantor namun tetap kita batasi. Pertama dimulai dari volume wajib pajak yang kita dibatasi, jadi filter awal yaitu didepan gerbang satpam kemudian kita buatkan ruang tunggu di luar gedung dan masuk kedalam untuk melakukan pelayanan secara virtual. Kita juga siapkan sarana dan prasarana seperti beberapa laptop dan PC untuk dipakai wajib pajak supaya bisa TPT virtual dengan petugas atau relawan pajak. Terkait kendala yang dialami relawan pajak sendiri kita dari petugas sudah siap untuk meng-back up segala kendala apapun yang dialami oleh relawan pajak misal ada yang kurang jelas dalam pengisiannya atau kendala koneksi yang dapat di dikoordinasikan melalui whatsapp group.
\end{abstract}

Dimasa pandemi covid-19 yang masih berlangsung di tahun 2021, KPP Pratama Bangkalan berharap wajib pajak dapat memanfaatkan adanya pelayanan TPT virtual untuk mencegah penyebaran virus covid19. Namun, kenyataan dilapangan masih terdapat wajib pajak yang datang langsung ke KPP untuk melaporkan SPT Tahunannya. Hal tersebut karena masih terdapat wajib pajak yang belum paham mengenai pelaporan SPT Tahunan melalui e-filing maupun memanfaatkan TPT virtual. Upaya yang dilakukan KPP saat wajib pajak tetap datang ke kantor yaitu menerapkan protokol kesehatan, membatasi volume wajib pajak per harinya, dan mempersiapkan sarana dan prasarana seperti laptop dan PC untuk dipakai wajib pajak agar tetap bisa TPT virtual dengan petugas atau relawan pajak. Untuk kendala pembagian jadwal satgas yang WFH dan WFO, upaya yang dilakukan yaitu mengatur pembagian jadwal agar tim satgas tetap menjalankan tugas fungsi utamanya disandingkan dengan tugas menjadi tim pelayanan. Selain itu, jika relawan pajak mengalami kendala saat pelayanan, petugas sudah siap membantu secara virtual dan dikoordinasikan melalui whatsapp group yang telah dibuat sebelumnya.

Hal yang sama juga dihadapi oleh relawan pajak. Dari 29 relawan pajak, 96,6\% menyatakan bahwa terdapat hambatan yang relawan pajak pada saat pelaksanaan asistensi pelayanan pelaporan SPT Tahunan secara virtual bersama KPP Pratama Bangkalan. Hambatan yang sering dihadapi relawan pajak antara lain adalah jaringan internet yang kurang stabil, wajib pajak yang kurang memahami teknologi, dan wajib pajak lupa password. 


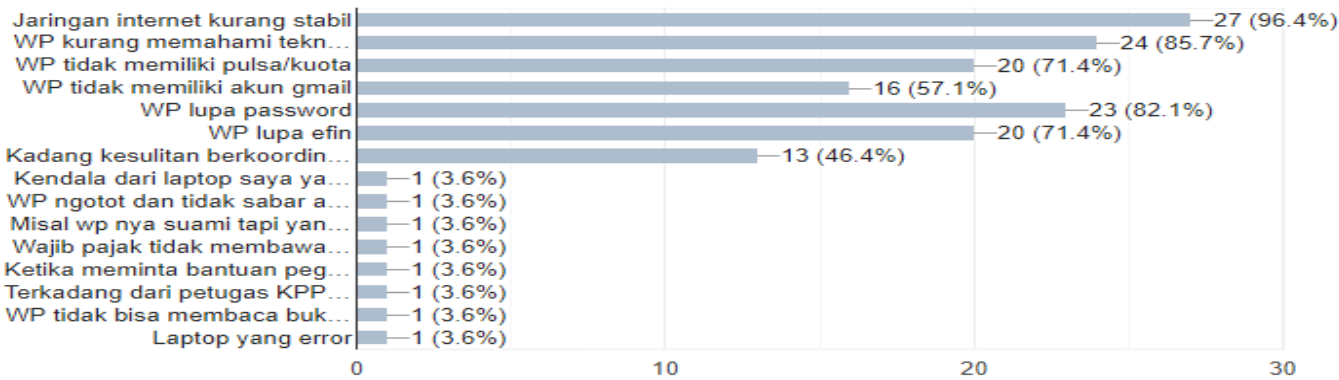

Gambar 3. Respon Hambatan yang Dihadapi Relawan Pajak dalam pelaksanaan TPT Virtual Sumber: Data Diolah, 2021

Menghadapi berbagai hambatan saat pelayanan pada TPT virtual, relawan pajak juga melakukan upaya untuk mengatasinya. Novita dan Ameliatus (relawan pajak) menjelaskan upaya yang dilakukan:

"1. Mencari tempat yang sinyalnya kuat 2. Jika WP lupa password/ email membuatkan password dan email baru 3. Jika WP kesusahan membaca bukti potong, akan dipandu membaca dengan mengshare screen contoh bukti potong dan meminta bantuan petugas di KPP untuk membimbing" (Novita)

"Apabila relawan pajak yang mengalami kendala sinyal, maka melaporkan kepada pegawai KPP Pratama Bangkalan agar bisa diambil alih. Lalu bila kendalanya adalah WP yang tidak dapat menggunakan teknologi, saya meminta wp untuk memanggilkan pegawai yang ada di kantor KPP untuk membantu beliau. Bila WP lupa nomor effin atau password, maka dapat meminta kepada KPP. Jika WP tidak memiliki akun email, maka relawan pajak akan membantu membuatkan" (Ameliatus)

Pelayanan pelaporan SPT secara virtual dilakukan di masing-masing daerah relawan pajak bertempat tinggal. Jaringan internet yang tidak stabil menjadi hambatan utama yang sebagian besar dihadapi oleh relawan pajak $(96,4 \%)$. Upaya yang dilakukan relawan pajak antara lain mencari tempat yang jaringan internet yang stabil, berkoordinasi dengan petugas pelayanan saat mengalami kendala yang tidak bisa diatasi sendiri melalui whatsapp group, serta berusaha membantu wajib pajak jika mengalami kendala (seperti lupa password, no efin, dan tidak memiliki akun email). Adapun beberapa saran relawan pajak untuk pelaksanaan asistensi pelaporan SPT Tahunan secara virtual bersama KPP Pratama Bangkalan ke depannya. Farida dan Septian (relawan pajak) menjelaskan:

"Mungkin untuk tahun berikutnya relawan bisa melaksanakannya di kantor KPP lagi dan diberi ruangan khusus untuk pelayan secara virtual agar segala kendala bisa langsung terbackup dan tidak saling menunggu" (Farida)

"Kiranya kedepan ada penyuluhan bukan hannya terhadap pihak relawan pajak namun juga masyarakat supaya kepatuhan pajak tidak terhambat akibat ketidakpahaman WP terhadap teknologi." (Septian)

Pelayanan pelaporan SPT Tahunan secara virtual pada masa pandemi, kedepannya diharapkan dapat berjalan lebih baik lagi. Relawan pajak berharap dapat melakukan pelayanan di KPP secara langsung meskipun pelayanan kepada wajib pajak tetap dilakukan secara virtual. Hal tersebut agar relawan pajak dapat berkoordinasi lebih mudah dengan petugas pelayanan saat mengalami kendala. Selain itu, sosialisasi kepada masyarakat tentang teknologi dan TPT virtual dapat lebih ditingkatkan. Hal tersebut bertujuan agar pelayanan pelaporan SPT dapat berjalan lancar serta efektif meskipun di masa pandemi covid-19.

Dimasa pandemi covid-19 saat ini, dimana pelaporan SPT Tahunan yang dilaksanakan secara virtual menjadi tantangan tersendiri. Tidak hanya bagi pegawai pajak dan relawan pajak, namn juga bagi wajib pajak. Masih terdapat wajib pajak yang melaporkan SPT Tahunan dengan cara mendatangi KPP secara langsung. Hal tersebut disebabkan masih terdapat wajib pajak yang belum memahami dan mengerti 
bagaimana melaporkan SPT Tahunan mengunakan e-filing dan memanfaatkan TPT virtual. Penjelasan Putri (bukan nama sebenarnya, berprofesi sebagai pegawai negeri sipil) mengenai pelayanan pelaporan SPT Tahunan tahun pajak 2020 di masa pandemi:

"Awal mulanya saya diberi peringatan oleh pihak kantor. Jadi di kantor itu sudah ada daftarnya siapa saja yang belum melaporkan kewajiban pajaknya kalau tidak salah itu hari terakhir pelaporan di bulan maret. Setelah itu saya datang langsung ke KPP untuk pelaporan SPT tahunannya mbak. Karena saya belum mengerti menggunakan e-filing"

"Untuk pelayanannya sendiri pertama saya datang, saya langsung diberi nomor antrean oleh bapak satpam disana. Setelah itu saya diarahkan menuju ke ruang pelayanan. Setelah sampai diarahkan kembali untuk mengisi e-filing secara online dengan dibantu oleh pegawai pajak secara virtual. Untuk pegawainya sendiri sangat ramah kepada wajib pajak. Kondisi KPP Pratama saat itu ramai namun tidak terlihat ramai karena suasananya sangat kondusif serta tertata dengan baik. Saya sangat merasa terbantu karena saat pengisian e-filing saya hanya disuruh membacakan isi bukti potongnya lalu petugas pajak yang disana yang membantu untuk mengisikan. Waktu yang saya habiskan disana pun hanya sebentar karena diarahkan dengan baik sehingga cepat sekali pelayanannya.

Dalam melaporkan SPT Tahunan tahun 2020, Putri mendatangi KPP secara langsung. Hal tersebut dilakukan karena belum memahami penggunaan e-filing untuk pelaporan SPTannya. Menurutnya pelayanan pegawai pajak sudah baik. Pada saat pelaporan SPT Tahunan, Putri merasa sangat terbantu dan dilayani dengan baik oleh petugas pajak. Pada saat pelaporan SPT Tahunan, Putri juga mengalami hambatan. Namun, hambatan tersebut sudah dibantu oleh petugas pajak dan terselesaikan dengan baik. Sejalan dengan pernyataan Putri sebagai berikut:
"Kendalanya sendiri itu di bukti potong yang diberikan itu tulisannya terlalu kecil, jadi saya sangat kesusahan untuk membacanya. Selain itu akses untuk masuk ke DPJ online juga kesusahan, misal kendala seperti lupa password ... Untuk hambatan yang saya alami sendiri petugas KPP Pratama langsung tanggap saat saya meminta pertolongan. Bapak satpam disana sangat membantu saya, jadi bapak satpam yang membantu membacakan isi formulirnya, saya sembari mengisinya, benar-benar di arahkan dengan baik. Untuk kendala akses masuk DJP online sangat teratasi dengan baik karena dibantu dan dipandu oleh petugas disana. Bahkan pada saat kita ngantri disaat ada kursi kosong malah di didatangi serta ditarahkan harus kemana selanjutnya oleh beberapa pegawai KPP sendiri"

Saat melaporkan SPT Tahunan, Putri menghadapi beberapa hambatan. Kesulitan membaca bukti potong dan lupa password akun djp onlinenya merupakan hambatan yang dihadapi saat pelaporan. Hambatan tersebut segera teratasi karena langsung dibantu/dipandu oleh petugas pelayanan/pegawai pajak dan juga dibantu oleh satpam yang saat itu sedang bertugas. Pelaporan SPT Tahunan berjalan baik dan wajib pajak merasa terbantu atas pelayanan yang diberikan oleh pegawai pajak. KPP Pratama Bangkalan juga berharap dapat terus memaksimalkan pelayanannya, berikut penjelasan Bapak Agus:
"Dengan adanya sosialisasi yang kita gencar selama satu tahun ini harapan salah satunya yang tidak kalah penting yaitu kesadaran Wajib Pajak untuk melaksanakan kewajiban perpajakannya dalam penyampaian SPT Tahunan bisa lebih bagus lagi, terutama melalui e-filing. Jadi seperti konsep yang dibuat awal oleh DJP dan KPP yaitu konsep wajib pajak yang mandiri bisa melakukan kewajiban pajaknya dimanapun tanpa harus datang ke KPP. Jika pandemi belum usai dan kebijakan pemerintah mengenai pembatasan tetap berlanjut, KPP akan terus running lagi TPT virtual yang tentunya kita tetap melibatkan relawan pajak dari Tax Centre FEB UTM namun dikemas dengan konsep, sarana dan prasarana serta teknis pelaksanaan yang lebih disempurnakan lagi.

Sosialisasi penyampaian SPT Tahunan melalui e-filing terus gencar dilakukan oleh KPP Pratama Bangkalan dan juga di unit lingkungan kerja DJP. Harapannya wajib pajak dapat melaporkan SPT Tahunannya tanpa harus datang langsung ke KPP dan kesadaran wajib pajak dapat meningkat. Mengingat di tahun 2021 pandemi covid-19 belum berakhir dan diharapkan semua lapisan masyarakat bekerjasama untuk mencegah penyebaran virus covid-19. Jika pandemi belum usai dan kebijakan pemerintah mengenai 
pembatasan tetap berlanjut, KPP Pratama Bangkalan akan tetap melaksanakan TPT virtual yang tentunya melibatkan relawan pajak dari Tax Centre FEB UTM. Kedepan harapannya dapat dikemas dengan konsep, sarana dan prasarana serta teknis pelaksanaan yang lebih disempurnakan lagi.

Teori atribusi mengargumentasikan bahwa perilaku seseorang ditentukan oleh kombinasi antara kekuatan internal dan eksternal. Relevansi teori atribusi dengan penelitian ini yaitu terletak pada penentuan sikap patuh atau tidak patuh oleh wajib pajak untuk memenuhi kewajiban perpajakannya. Kekuatan internal terhadap kepatuhan wajib pajak antara lain seperti kepribadian, persepsi diri, kemampuan, dan motivasi. Intensi wajib pajak untuk menerapkan maupun menggunakan e-filling dalam pelaporan SPT, juga erat kaitannya dengan perilaku wajib pajak yang disebabkan oleh dorongan eksternal. Dorongan eksternal antara lain seperti kondisi sosial, nilai-nilai sosial, lingkungan, dan pandangan masyarakat. Kepatuhan wajib pajak disebabkan pula oleh atribusi eksternal melalui peran relawan pajak dan pegawai pajak yang dipercayai mampu memberi kontribusi positif.

\section{KESIMPULAN, SARAN, DAN KETERBATASAN}

Pelayanan pelaporan SPT Tahunan wajib pajak orang pribadi melalui e-filing pada KPP Pratama Bangkalan bersama relawan pajak dimasa pandemi di tahun 2021 menjadi tantangan tersendiri. Pelayanan pada KPP dilakukan melalui TPT (Tempat Pelayanan Terpadu) virtual. Dimulai dari tahapan persiapan. Persiapan KPP antara lain dimulai dengan pembentukan tim satgas dengan melibatkan seluruh pelaksana, melakukan sosialisasi kepada masyarakat terkait fasilitas TPT virtual, persiapan koordinasi dilakukan bersama Tax Center FEB UTM beserta relawan pajak, memberikan pelatihan dan pembekalan (salah satunya berupa pedoman TPT virtual) kepada relawan pajak, mempersiapkan sarana dan prasarana, serta menyusun jadwal penugasan tiap shift. Relawan pajak pun juga turut melakukan berbagai persiapan, antara lain yaitu relawan pajak mengikuti pembekalan dan pelatihan terkait pelaporan SPT Tahunan baik dari KPP Pratama Bangakalan dan juga Tax Center, memahami pedoman TPT virtual, mempersiapkan sarana dan prasarana, serta melakukan sharing dengan relawan pajak lainnya. Dari tahap persiapan dan pelaksanaan, menurut relawan pajak sudah berjalan sangat baik, meskipun dalam proses pelayanan masih menghadapi berbagai hambatan.

Hambatan yang dihadapi oleh KPP Pratama Bangkalan antara lain yaitu masih terdapat wajib pajak yang datang langsung ke KPP, pembagian jadwal satgas yang wfh dan wfo, kadang terkendala sinyal, dan relawan pajak mengalam kendala saat asistesi pelayanan. Upaya yang dilakukan KPP yaitu menerapkan protokol kesehatan, membatasi volume wajib pajak per harinya, mempersiapkan sarana dan prasarana seperti laptop dan PC untuk dipakai wajib pajak agar tetap bisa TPT virtual dengan petugas atau relawan pajak, mengatur pembagian jadwal agar tim satgas tetap menjalankan tugas fungsi utamanya, dan jika relawan pajak mengalami kendala petugas sudah siap membantu secara virtual dan dikoordinasikan melalui whatsapp group. Hal yang sama juga dihadapi oleh relawan pajak. Dari 29 relawan pajak, 96,6\% menyatakan bahwa terdapat hambatan yang relawan pajak pada saat pelaksanaan asistensi pelayanan pelaporan SPT Tahunan secara virtual bersama KPP Pratama Bangkalan. Hambatan yang sering dihadapi relawan pajak antara lain adalah jaringan internet yang kurang stabil, wajib pajak yang kurang memahami teknologi, dan wajib pajak lupa password. Upaya yang dilakukan relawan pajak antara lain mencari tempat yang jaringan internet yang stabil, berkoordinasi dengan petugas pelayanan saat mengalami kendala yang tidak bisa diatasi sendiri melalui whatsapp group, serta berusaha membantu wajib pajak jika mengalami kendala (seperti lupa password atau no efin, dan tidak memiliki akun email).

Meskipun terdapat beberapa hambatan dalam pelaksanaan pelayanan secara virtual, namun dapat teratasi dengan baik. Selain itu, tanggapan wajib pajak terhadap pelayanan KPP juga sudah berjalan baik. Wajib pajak yang melaporkan SPT Tahunan berusaha dilayani semaksimal mungkin. Keterbatasan penelitian yaitu penelitian ini hanya sebatas menggambarkan pelayanan pelaporan SPT Tahunan dimasa pandemi covid-19 dari sudut pandang wajib pajak. Saran untuk penelitian selanjutnya dengan menambah informan penelitian seperti pegawai pajak (seksi ekstensifikasi) dan memperluas cakupan wajib pajak, sehingga penelitian dapat dilakukan lebih mendalam dan komprehensif. Juga penelitian selanjutnya dapat menggunakan metode kuantitaif. Diharapkan penelitian ini dapat menjadi bahan evauasi bagi KPP Pratama Bangkalan dan unit kerja di lingkungan DJP dalam meningkatkan performance pelayanan 
pelaporan SPT Tahunan secara virtual bersama relawan pajak, meskipun pelayanan virtual di masa pandemi ini menjadi tantangan tersendiri. Adapun bagi wajib pajak diharapkan dapat memanfaatkan layanan pajak secara virtual semaksimal mungkin dan tetap patuh melaporkan SPT Tahunan meski dimasa pandemi covid-19.

\section{Ucapan Terima Kasih}

Penelitian ini didukung oleh LPPM Universitas Trunojoyo dengan Hibah Riset Mandiri 2021, Nomor 3179/UN46.4.1/PT.01.03./2021

\section{DAFTAR PUSTAKA}

Agustiningsih, W., \& Isroah, I. (2016). Pengaruh Penerapan E-Filing, Tingkat Pemahaman Perpajakan dan Kesadaran Wajib Pajak Terhadap Kepatuhan Wajib Pajak di KPP Pratama Yogyakarta. Nominal, Barometer Riset Akuntansi Dan Manajemen, 5(2). https:/ / doi.org/10.21831/nominal.v5i2.11729

Artawan, I. G. P., Widnyana, I. W., \& Kusuma, I. G. A. T. (2020). The Effect of Service Quality to Build Taxpayer Trust and Satisfaction on Increasing Taxpayer Compliance in Gianyar Regency. International Journal of Contemporary Research and Review, 11(09), 21868-21883. https://doi.org/10.15520/IJCRR.V11I09.842

Covid19.go.id. (2021). Pemberlakuan Pembatasan Kegiatan Masyarakat (PPKM) Berbasis Mikro, 9 - 22 Februari 2021. https://covid19.go.id/p/masyarakat-umum/pemberlakuan-pembatasan-kegiatan-masyarakatppkm-berbasis-mikro-9-22-februari-2021

Creswell, J. W. (2014). Research Design Pendekatan Kualitatif, Kuantitatif, dan Mixed. Yogyakarta: Pustaka Belajar.

Darmayasa, I. N., Wibawa, B. P., \& Nurhayanti, K. (2020). E-Filling dan Relawan Pajak dalam Meningkatkan Kepatuhan Wajib Pajak Orang Pribadi. Jurnal Kajian Akuntansi, 4(2), 208-227. https://doi.org/10.33603/JKA.V4I2.3949

DDTC.go.id. (2020). Apa Itu Kepatuhan Pajak? https://news.ddtc.co.id/apa-itu-kepatuhan-pajak-19757

DJP. (2020a). Laporan Kinerja Direktorat Jenderal Pajak 2020. https://www.pajak.go.id/sites/default/files/2021-02/LAKIN DJP 2020.pdf

DJP. (2020b). Saluran Komunikasi Pelayanan SPT Tahunan di Lingkungan Kanwil Suluttenggomalut. https://www.pajak.go.id/id/siaran-pers/saluran-komunikasi-pelayanan-spt-tahunan-dilingkungan-kanwil-suluttenggomalut

DJP. (2021). Terima Kasih Relawan Pajak, Ini Harapan ke Depan. https://pajak.go.id/id/artikel/terima-kasihrelawan-pajak-ini-harapan-ke-depan

Dwianika, A., Nurhidayah, F., \& Azizah, N. N. (2018). Relawan Pajak: Tidak Hanya Sekedar Mengerti Pajak (Motivasi Layanan dan Kepuasan WPOP/UMKM). Seminar Hasil Pengabdian Kepada Masyarakat, 14-20.

Dwianika, A., \& Sofia, I. P. (2019). Relawan Pajak: Bagaimana Pelatihan Pajak Mempengaruhi Kepuasan Wajib Pajak pada Masyarakat Urban? (Studi pada Tax Centre Universitas Pembangunan Jaya). Keberlanjutan, 4(2), 1176. https:// doi.org/10.32493/ keberlanjutan.v4i2.y2019.p1176-1191

Edukasi pajak.go.id. (2020). Nota Dinas Relawan Pajak. http://edukasi.pajak.go.id/images/relawan_pajak/ND_RELAWAN_2020.pdf

Kamayanti, A. (2016). Metodologi Penelitian Kualitatif Akuntansi Pengantar Religiositas Keilmuan. Malang: Yayasan Rumah Peneleh.

Kemenkeu.go.id. (2020). Penerimaan Pajak Capai Rp1.019,56 Triliun atau 85,65\% dari Target. https://www.kemenkeu.go.id/publikasi/berita/penerimaan-pajak-capai-rp1019-56-triliun-atau-8565-dari-target/

Putri, K. J., \& Setiawan, P. E. (2017). Pengaruh Sanksi Perpajakan, Pelayanan Fiskus, Pengetahuan Dan Pemahaman Perpajakan, Kesadaran Perpajakan Terhadap Kepatuhan Wajib Pajak. Pengaruh Sanksi Perpajakan, Pelayanan Fiskus, Pengetahuan Dan Pemahaman Perpajakan, Kesadaran Perpajakan Terhadap Kepatuhan Wajib Pajak, 6(3), 136-148.

Suartana, I. W. (2010). Akuntansi Keprilakuan Teori dan Implementasi. Denpasar : Andi Offset.

Susmita, P. R., \& Supadmi, N. L. (2016). Pengaruh Kualitas Pelayanan, Sanksi Perpajakan, Biaya Kepatuhan Pajak, dan Penerapan E-Filing pada Kepatuhan Wajib Pajak. E-Jurnal Akuntansi, 14(2), 1239-1269.

Syakura, M. A., \& Baridwan, Z. (2014). Determinan Perencanaan Pajak dan Perilaku Kepatuhan Wajib 
Pajak Badan.

Jurnal

Akuntansi

Multiparadigma,

$5(2)$,

185-201.

https://doi.org/10.18202/jamal.2014.08.5017

Undang-Undang Nomor 28 Tahun 2007. (n.d.). Retrieved October 6, 2021, from https://pajak.go.id/id/undang-undang-nomor-28-tahun-2007

Weiner, B. (2010). Attribution Theory. The Corsini Encyclopedia of Psychology. https:// doi.org/10.1002/9780470479216.corpsy0098

Yasa, I. N. P., Artini, N. M. A. S. P., Astari, L. M., \& Sari, N. P. P. (2021). Mengungkap Persepsi Wajib Pajak Atas Pendampingan Relawan Pajak. Jurnal Akuntansi Bisnis, 14(1). https://doi.org/10.30813/JAB.V14I1.2453 
